\title{
Nuclear Accumulation of $\boldsymbol{\beta}$-Catenin in Cancer Stem Cell Radioresistance and Stemness in Human Colon Cancer
}

\author{
HIDEKAZU TANAKA ${ }^{1,2^{*}}$, MASAYA KAWAGUCHI ${ }^{1,3 *}$, SHINICHI SHODA ${ }^{1,4}$, \\ TOSHIHARU MIYOSHI ${ }^{4}$, RYOTA IWASAKI ${ }^{5}$, FUMINORI HYODO ${ }^{1,6}$, \\ TAKASHI MORI $^{7,8}$, AKIRA HARA ${ }^{3}$, HIROYUKI TOMITA ${ }^{3}$ and MASAYUKI MATSUO ${ }^{1}$ \\ ${ }^{1}$ Department of Radiology, Gifu University Graduate School of Medicine, Gifu, Japan; \\ ${ }^{2}$ Department of Radiation Oncology, Yamaguchi University Graduate School of Medicine, Ube, Japan; \\ ${ }^{3}$ Department of Tumor Pathology, Gifu University Graduate School of Medicine, Gifu, Japan; \\ ${ }^{4}$ Department of Radiology Service, Gifu University Hospital, Gifu, Japan; \\ ${ }^{5}$ Animal Medical Center, Gifu University, Gifu, Japan; \\ ${ }^{6}$ Department of Frontier Science for Imaging, Gifu University Graduate School of Medicine, Gifu, Japan; \\ ${ }^{7}$ Department of Veterinary Clinical Oncology, Faculty of Applied Biological Sciences, Gifu University, Gifu, Japan; \\ ${ }^{8}$ Center for Highly Advanced Integration of Nano and Life Science, Gifu University, Gifu, Japan
}

\begin{abstract}
Background/Aim: The aim of this study was to examine whether the Wnt/ $\beta$-catenin signal activation is a cause of radioresistance in colon cancer by assessing the $\beta$-catenin localization and its correlation with cancer stem cells (CSCs). Materials and Methods: The nuclear levels of $\beta$-catenin, the hallmark of Wnt activation, were analyzed in HCT116 and SW480 cells by immunohistochemistry, before and after irradiation. Further, we assessed CSC populations by staining for aldehyde dehydrogenase-1 (ALDH1) and CD44. Results: $\beta$-catenin was localized predominantly in the nucleus and plasma membrane in SW480 and HCT116 cells, respectively. Compared to HCT116 cells, SW480 cells displayed higher Wnt activation. At 24 h after irradiation, most of the DSBs in SW480 cells were repaired, but were still present in HCT116 cells. Additionally, compared to HCT116 cells, a significantly higher proportion of SW480 cells were ALDH1- and CD44-positive. Conclusion: Colon cancers with nuclear $\beta$-catenin accumulation demonstrated greater radio-resistance with a higher number of CSCs.
\end{abstract}

*These Authors contributed equally to this study.

Correspondence to: Hiroyuki Tomita, Department of Tumor Pathology, Gifu University Graduate School of Medicine, 1-1 Yanagido, Gifu 501-1194, Japan. Tel: +81 582306225, e-mail: h_tomita@gifu-u.ac.jp

Key Words: Wnt/ $\beta$-catenin signaling pathway, cancer stem cell, radioresistance, colorectal cancer, $\beta$-catenin.
There are two $\mathrm{Wnt} / \beta$-catenin signaling pathways: the canonical pathway and the non-canonical pathway $(1,2)$. $\beta$-catenin is the key molecule in the canonical Wnt pathway. In Wnt-off state, $\beta$ catenin in the cytoplasm is within a protein complex composed of adenomatous polyposis coli (APC), Axin, glycogen synthase kinase $3 \beta(\mathrm{GSK} 3 \beta)$, and casein kinase $1 \alpha(\mathrm{CK} 1 \alpha)$, and phosphorylated by GSK3 $\beta$ and $\mathrm{CK} 1 \alpha$. Then, $\beta$-catenin is ubiquitinated and targeted for destruction by the proteasome. As a result, the amount of $\beta$-catenin is low. Conversely, in the Wnton state, Wnt ligands bind to the receptor complex composed of a Frizzled (Fz) receptor and low-density lipoprotein receptorrelated proteins (LRP5/6). This receptor recruits Disheveled (Dvl) to the plasma membrane. Dvl forms a complex with Axin, Fz, and LRP5/6 and acts as a direct competitive inhibitor of GSK3 $\beta$. Thus, $\beta$-catenin escapes phosphorylation and accumulates in the cytoplasm. The stabilized $\beta$-catenin translocates into the nucleus, where it serves as a transcriptional co-activator and influences gene transcription. Thus, $\beta$-catenin localization to the nucleus reflects Wnt activity (3-5).

The canonical $\mathrm{Wnt} / \beta$-catenin signaling pathway plays an important role in cell proliferation, growth, and differentiation $(6,7)$. Mutations in Wnt signaling pathway components cause many diseases, including cancer. Furthermore, dysregulation of the Wnt signaling pathway is associated with the expansion of stem cell and progenitor cell lineages and is also highly associated with carcinogenesis (8-10). Most colorectal cancer (CRC) cases are caused by mutations in Wnt signaling pathway components (11-13). Originally, a mutation in the APC gene was associated with familial adenomatous polyposis (FAP). Approximately $1 \%$ of FAP cases progress to CRC $(14,15)$. Furthermore, $85 \%$ of sporadic intestinal neoplasia cases have mutations in APC, whereas activating 
mutations in $\beta$-catenin are found in approximately $50 \%$ of CRC tumors without APC mutations $(16,17)$. The Wnt signaling pathway is related to both carcinogenesis and treatment resistance (18). Several reports have evaluated the correlation between the Wnt signaling pathway and resistance to chemotherapy $(19,20)$. Several attempts to discover new drugs targeting the Wnt signaling pathway and to improve chemo-resistance have been made (21-23). Although the relationship between the Wnt signaling pathway and chemoresistance has been well studied, their relationship with radioresistance remains unclear.

The Wnt signaling pathway is responsible for designating cancer stem cells (CSCs) (24). The nuclear localization and subsequent activation of $\mathrm{T}$ cell factor (TCF) transcription is an important process in CSCs (25). CD44 is a multifunctional cell surface adhesion protein that reacts with extracellular matrix components. Increased CD44 expression leads to enhanced CSC properties in colon cancer cells $(26,27)$. There are also reports showing that the combination of CD44 and CD133 is correlated with features of CSCs (28). CD44 helps to facilitate cell-cell and cell-matrix interactions through its affinity for hyaluronic acid; it is also involved in cell adhesion and the assembly of growth factors on the cell surface (29). Increased resistance to radiation therapy has been reported in CD44 ${ }^{\text {high }}$ cells compared to CD44 ${ }^{\text {low }}$ cells (29-31).

The aldehyde dehydrogenase (ALDH) family of enzymes are cytosolic isoenzymes responsible for oxidizing intracellular aldehydes and retinol to retinoic acid in early stem cell differentiation (32). ALDH1 is expressed in various normal stem and progenitor cells and contributes to cell proliferation and differentiation $(27,33)$. Some reports have shown that nuclear localization of ALDH1A1 is associated with a dismal prognosis in clinical CRC cases $(34,35)$. ALDH1 is also correlated with radioresistance $(31,36,37)$.

The epithelial cell adhesion molecule (EpCAM) is also known as an epithelial-specific antigen. EpCAM was initially discovered as a predominant antigen in human colon carcinoma; it is a transmembrane glycoprotein that is highly expressed in rapidly proliferating carcinomas (38). Recent data have suggested a more multifaceted role of EpCAM in not only cell-cell adhesion but also cell signaling, migration, proliferation, and differentiation (39). EpCAM is also reported to be a putative CSC marker (40). EpCAM expression is also correlated with radioresistance (41).

This study focused on the localization of $\beta$-catenin and analyzed its correlation with radioresistance and cancer stemlike cells.

\section{Materials and Methods}

Cell culture. Two human CRC cell lines, HCT116 and SW480 (American Type Culture Collection, Manassas, VA, USA), were maintained in culture using standard protocols. The HCT116 cell line was cultured in McCoy's 5A medium (American Type Culture Collection, Manassas, VA, USA) supplemented with $10 \%$ fetal bovine serum and $1 \%$ penicillin-streptomycin. The SW480 cell line was cultured in Leibovitz's L-15 medium (American Type Culture Collection, Manassas, VA, USA) supplemented with $10 \%$ fetal bovine serum and $1 \%$ penicillin-streptomycin.

Irradiation. Photon irradiation was delivered by a Primus system (Siemens Healthcare, Malvern, PA, USA). The photon energy was $4 \mathrm{MV}$ and the dose rate was 250 monitor units per min. Cells were plated into dishes at approximately 50\% confluency. Twenty-four $h$ after plating, a 1-cm bolus was put on dishes and the cells in dishes were irradiated.

Clonogenic assay. Each cell line was irradiated in dishes with 0 (control), 2, 4, and $8 \mathrm{~Gy}$, respectively. Subsequently, 100 and 1,000 cells were re-plated. After 14 days of cultivation, the cells were rinsed with phosphate buffer saline. A 3-ml of $6.0 \%$ glutaraldehyde and $0.5 \%$ crystal violet was then added and incubated for $30 \mathrm{~min}$. The glutaraldehyde crystal violet mixture was then rinsed with water and the plate was allowed to dry in normal air at room temperature. Finally, the colonies were counted.

Cell block. The cell samples were fixed for one $\mathrm{h}$ by mixing with $10 \%$ buffered formalin. After one h, the samples were centrifuged at $1000 \mathrm{x} \mathrm{g}$ for $15 \mathrm{~min}$. The supernatant was discarded and a further fresh $100 \%$ and then $70 \%$ alcohol was added to the sediment and incubated for one day. On the following day, the sediment containing the cells was processed along with other routine histopathological specimens.

IHC staining. A labeled streptavidin-biotin (LSAB) method was used for immunohistochemical (IHC) staining of deparaffinized 3- $\mu \mathrm{m}$ thick sections. The sections were placed in citrate buffer $(10 \mathrm{mmol}-$ 1, $\mathrm{pH}$ 6.0) and then autoclaved at a chamber temperature of $121^{\circ} \mathrm{C}$ for $1 \mathrm{~min}$ to retrieve the antigen. They were then rinsed and blocked in $3 \%$ hydrogen peroxide. Non-specific binding sites were blocked in $0.01 \mathrm{M}$ phosphate-buffered saline ( $\mathrm{pH} 7.4$ ) containing $2 \%$ bovine serum albumin (Wako Pure Chemical, Osaka, Japan) for $40 \mathrm{~min}$. The primary antibodies used were purified mouse anti- $\beta$-catenin [mouse immunoglobulin (IgG), 1:100, BD bioscience, CA, USA], antigamma H2A.X (phospho S139) antibody (rabbit IgG, 1:100, abcam, CA, UK), anti-ALDH1A1 antibody (ab52492) (rabbit IgG, 1:500, abcam, CA, UK), purified mouse anti-human CD44 (550392) (mouse $\mathrm{IgG}, 1: 25$, BD Pharmingen, NJ, USA), and anti-EpCAM antibody (ab71916) (rabbit IgG, 1:50, abcam, Cambridge, UK).

\section{Results}

Localization of $\beta$-catenin in colorectal cancer (CRC) cell lines. To investigate the localization of $\beta$-catenin, the hallmark of Wnt activation, in CRC cell lines, we performed IHC with $\beta$-catenin antibody in SW480 and HCT116 CRC cell lines, which have similar protein expression levels in western blot analysis $(42,43)$. HCT116 cells express wildtype APC and mutant $\beta$-catenin, while SW480 cells express mutant APC. SW480 cells had one mutant allele with loss of the other allele (44). $\beta$-catenin expression was localized in the nucleus and cytoplasm of SW480 cells and in the 


\section{HCT116 SW480}

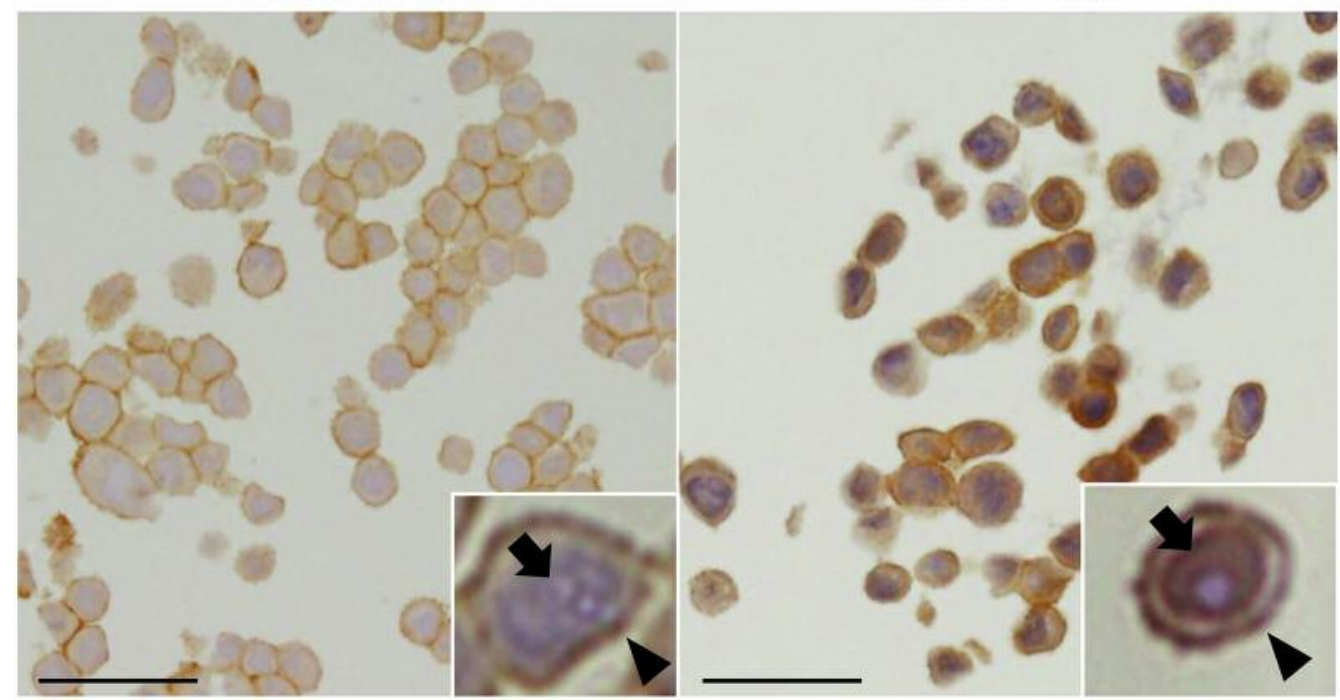

Figure 1. Expression of $\beta$-catenin in HCT116 and SW480 cells. In SW480 cells, $\beta$-catenin predominantly localized in the nucleus, whereas in HCT116 cells, it was primarily found in the plasma membrane. Arrow indicates cellular membrane. Arrowhead indicates nucleus. Scale bars: 50 um.

membrane of HCT116 cells (Figure 1). The results indicated that SW480 cells had a different Wnt/ $\beta$-catenin signaling pathway activation compared to HCT116 cells.

Comparison of DNA repair rates after irradiation. To assess the level of DNA double-strand break (DSB) repair after irradiation, expression of $\gamma \mathrm{H} 2 \mathrm{AX}$, a surrogate marker of DSBs, was evaluated in both SW480 and HCT116 cell lines after 4 Gy irradiation. The number of foci was significantly lower in SW480 cells than that in HCT116 cells at $24 \mathrm{~h}$ after irradiation (Figure 2). These results suggested that nuclear $\beta$-catenin, the hallmark of Wnt activation, is associated with DSB repair at $24 \mathrm{~h}$ after irradiation.

Sensitivity of CRC cells to X-rays assessed by clonogenic assay. To measure the survival of both SW480 and HCT116 cells after irradiation, clonogenic assays were performed following 0,2, 4, and 8 Gy irradiation (Figure 3). Fourteen days after irradiation, colonies on each dish were counted. At each irradiation dose, the ratio of colony numbers to the control group (0 Gy) was calculated and expressed logarithmically. Figure 3 shows the results of clonogenic assays starting from 1,000 cells. There were significantly more colonies in SW480 cells than in HCT116 cells at 2, 4, and 8 Gy ( $p=0.0316,<0.0001$, and 0.0002 , respectively). Similarly, starting from 100 cells, the clonogenic assay showed significantly higher numbers of colonies in SW480 cells than those in HCT116 cells at 2, 4, and 8 Gy (data not shown). No colony formation was observed in the dishes where 100 HCT116 cells plated after 8 Gy irradiation. These results indicate that SW480 cells were more radioresistant compared to HCT116 cells. Taken together, Wnt-activated CRC cells may be radioresistant relatively to non-activated CRC cells.

Expression of CSC markers in Wnt-activated and nonactivated CRC cells. Next, to evaluate the correlation between putative CSC markers and nuclear $\beta$-catenin, IHC for ALDH1, CD44, and EpCAM was performed in each cell line. SW480 cells, which have high $\beta$-catenin accumulation in the nucleus, had a significantly higher proportion of ALDH1-positive cells compared to HCT116 cells, which showed almost exclusive membranous staining of $\beta$-catenin (Figure 4). Similar to ALDH1 expression, the proportion of CD44-positive SW480 cells was also significantly higher than that in HCT116 cells (Figure 5). In contrast, the proportion of EpCAM-positive SW480 cells was significantly lower than that in HCT116 cells (Figure 6). These results suggest that ALDH1 and CD44 expression may be radioresistant markers as well as nuclear $\beta$-catenin expression in CRC cells.

\section{Discussion}

When the $\mathrm{Wnt} / \beta$-catenin signaling pathway is active, $\beta$-catenin is not degraded; it accumulates and translocates into the nucleus. Thus, increased $\beta$-catenin levels in the nucleus indicate Wntactive status. In contrast, when Wnt is inactive, $\beta$-catenin is 
a

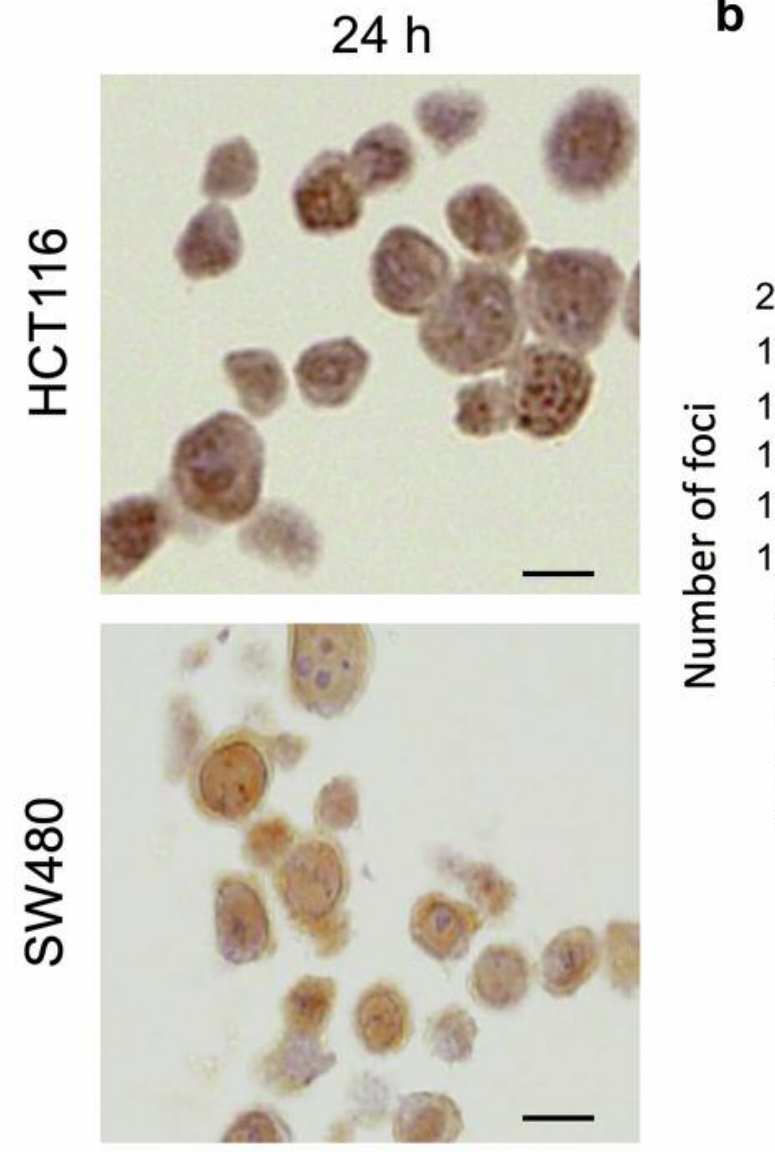

b

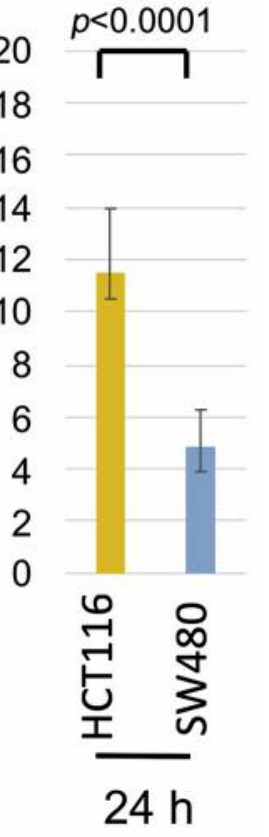

Figure 2. $\gamma H 2 A X$ expression after irradiation. (a) $\gamma H 2 A X$ foci after 4 Gy irradiation in HCT116 and SW480 cells. At 24 h after irradiation, most of the double-strand breaks (DSBS) in the SW480 cells are repaired, whereas they remain in the HCT116 cells. (b) The number of $\gamma H 2 A X$ foci in SW480 cells was significantly lower than that in HCT116 cells at $24 \mathrm{~h}$ after irradiation (Student's t-test; N=10). Scale bars: $10 \mu \mathrm{m}$.

degraded by the proteasome and the levels of $\beta$-catenin in the cytoplasm are decreased. Translocation into the nucleus does not occur because the cytoplasmic $\beta$-catenin level is not high. Therefore, higher $\beta$-catenin levels in the plasma membrane rather than the nucleus indicates inactive Wnt. In SW480 cells, $\beta$-catenin was predominantly observed in the nucleus, whereas it was primarily observed in the plasma membrane in HCT116 cells. SW480 cells showed higher Wnt/ $\beta$-catenin signaling pathway activation compared to HCT116 cells.

Photon beams have an anti-tumor effect by damaging tumor DNA. The DSB levels were assessed via $\gamma \mathrm{H} 2 \mathrm{AX}$, a surrogate marker of DSBs. At the early time point, there was no difference in DNA damage foci formation between HCT116 and SW480 cells. However, $24 \mathrm{~h}$ after irradiation, most of the DSBs in SW480 cells were repaired, but remained in HCT116 cells. The number of $\gamma \mathrm{H} 2 \mathrm{AX}$ foci in SW480 cells was significantly lower than that in HCT116 cells at $24 \mathrm{~h}$ after irradiation. Wnt signaling is related to
DNA damage repair, suggesting increased repair with high Wnt activity (45). This is considered to be one of the causes of resistance to treatment. Moreover, the results of the colony formation assay showed that SW480 cells, with higher Wnt activity, formed higher number of colonies and showed resistance to irradiation compared to HCT116 cells, with lower Wnt activity. This result was similar regardless of the irradiation dose and numbers of seeding cells.

Wnt signaling is also involved in CSC control (46-48). CD44, CD133, ALDH1, Lgr5, EpCAM, etc. are putative markers of CSC in colorectal cancer (26-28, 33, 35, 40, 49). Among them, we evaluated CD44, ALDH1, and EpCAM by IHC. Koh et al. have reported that activation of gastrin by $\beta$ catenin is an early event of colon carcinogenesis that promotes tumor development (50). Wnt signaling is enhanced by the secretion of progastrin, a direct target of the oncogenic $\mathrm{Tcf} / \beta$ catenin pathway $(51,52)$. Jin et al. have reported an increased proportion of CD44-positive cells following the addition of 
a

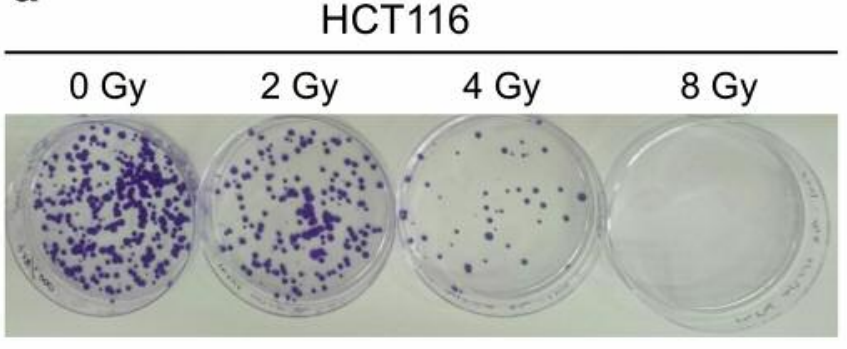

b

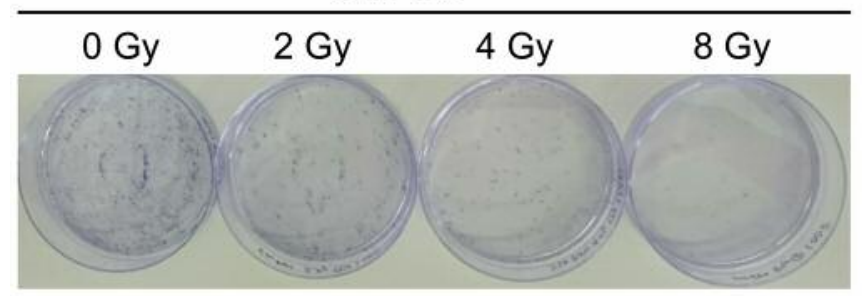

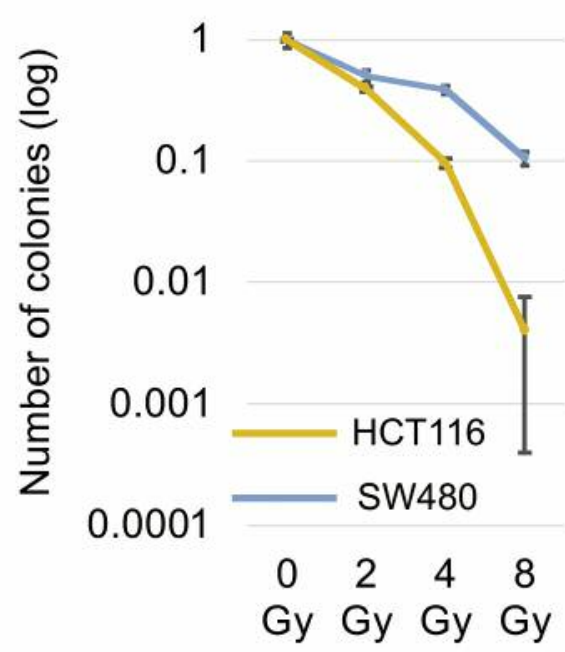

Figure 3. Colony formation after irradiation in SW480 and HCT116 cells. (a) Colony formation assay in HCT116 and SW480 cells. (b) Comparison of radioresistance between SW480 and HCT116 cells (Student's t-test; N=3). Scale bars: $10 \mu \mathrm{m}$.
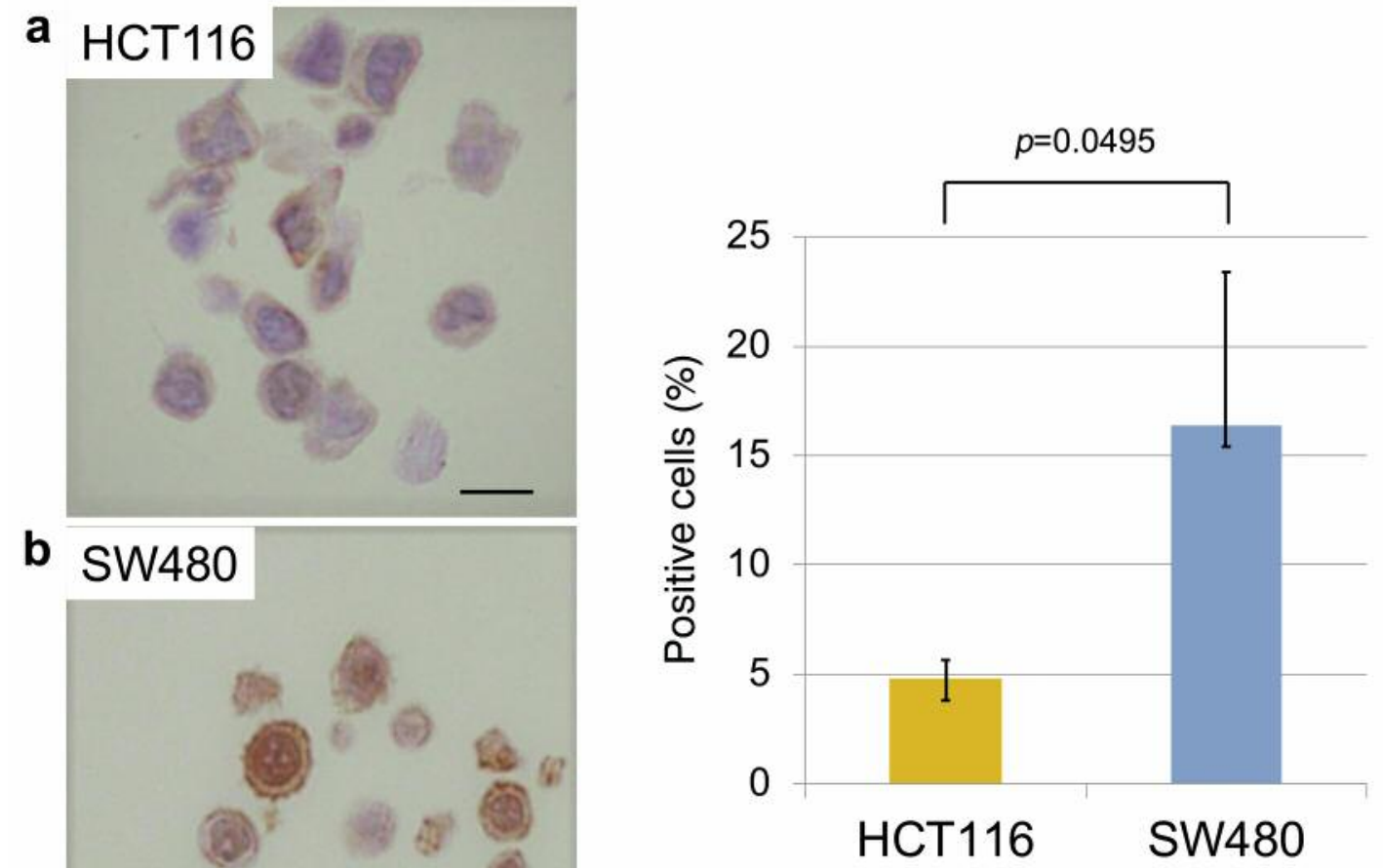

Figure 4. ALDH1 expression in HTC116 and SW480 cells. (a) Expression of ALDH1 in HTC116 and SW480 cells. (b) SW480 cells had a significantly higher proportion of ALDH1-positive cells compared to HCT116 cells (Student's t-test; N=5). Error bars represent the standard deviation of the mean value. Scale bars: $10 \mu \mathrm{m}$. 

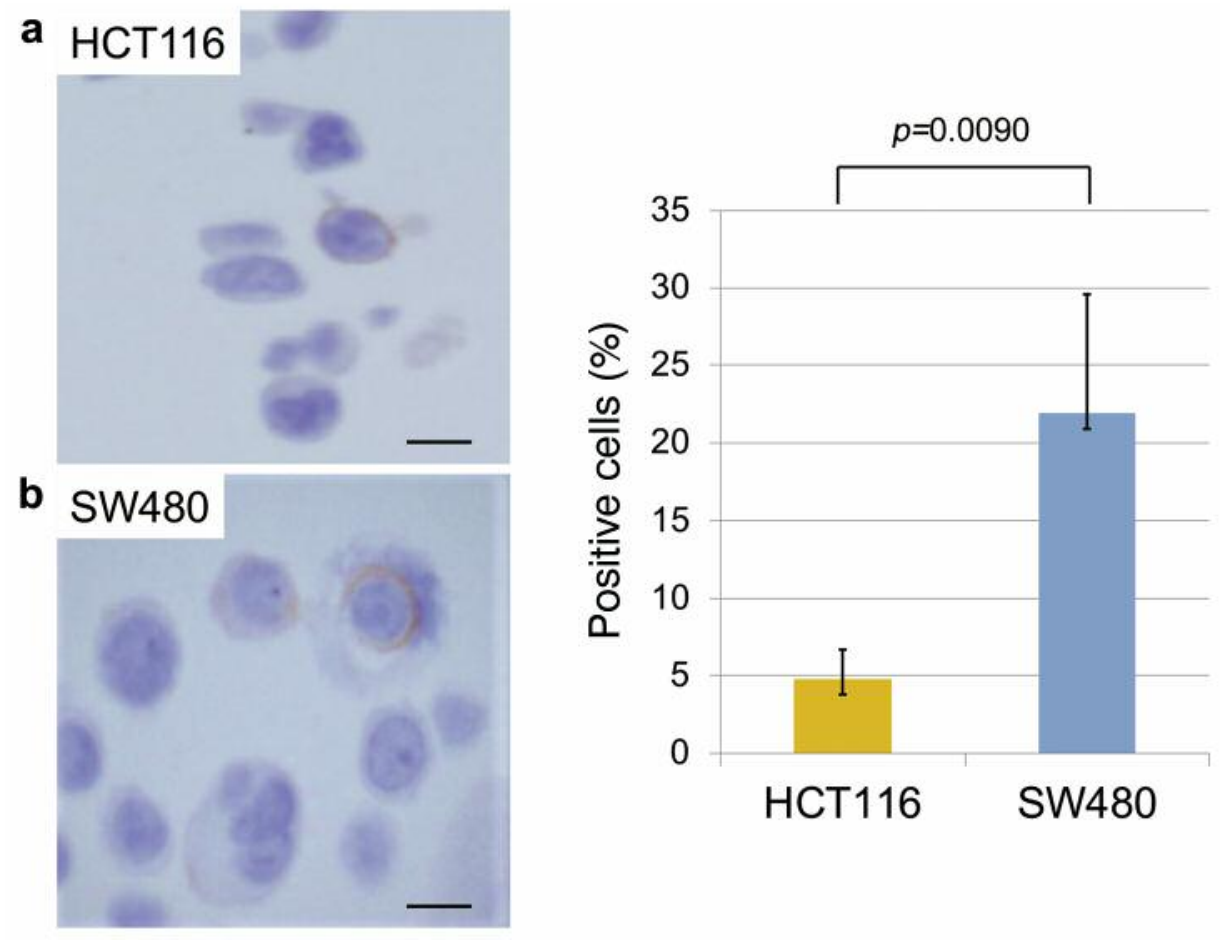

Figure 5. CD44 expression in HTC116 and SW480 cells. (a) Expression of CD44 in HTC116 and SW480 cells. (b) SW480 cells had a significantly higher proportion of CD44-positive cells compared to HCT116 cells (Student's t-test; $N=5$ ). Error bars represent the standard deviation of the mean value. Scale bars: $10 \mu \mathrm{m}$.
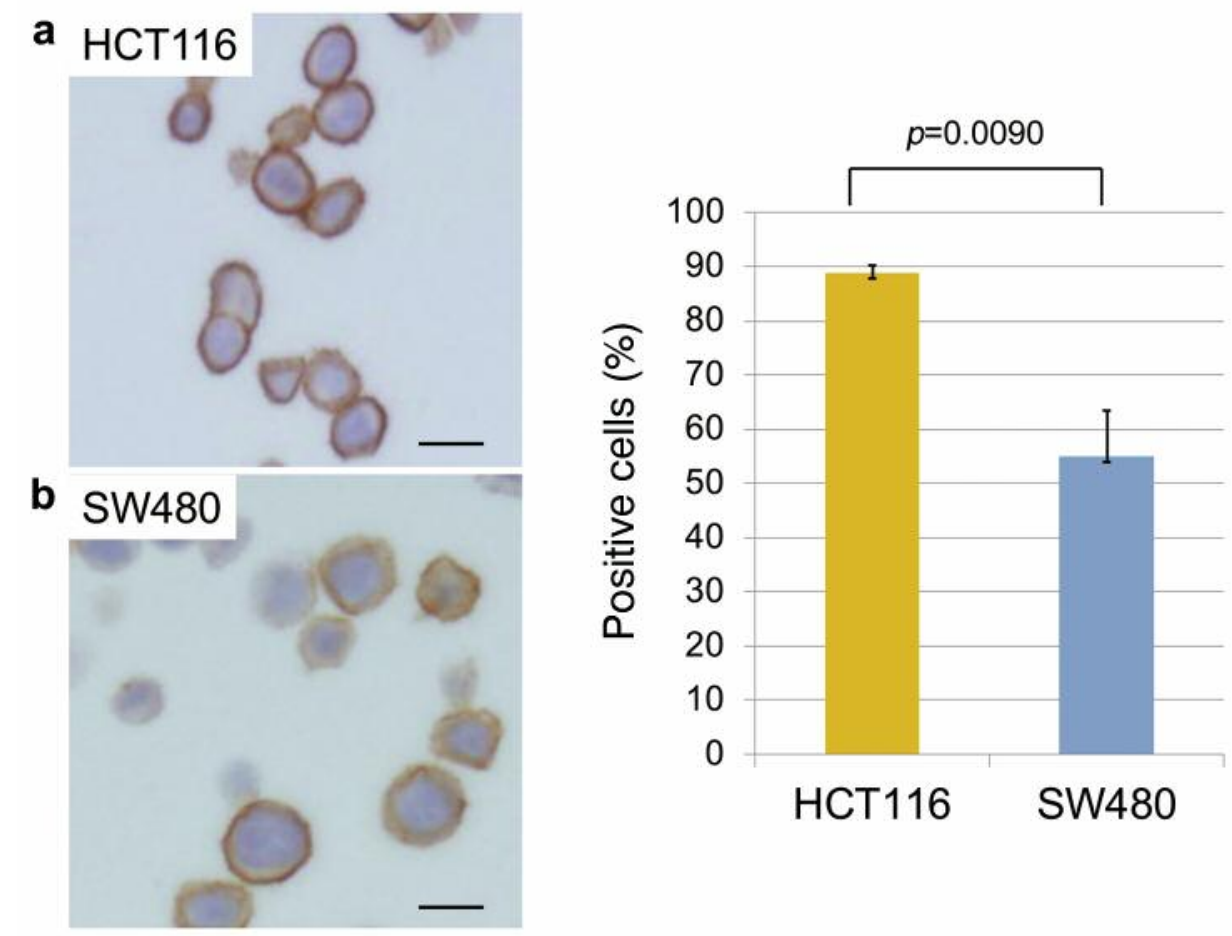

Figure 6. EpCAM expression in HCT116 and SW480 cells. Expression of EpCAM in HCT116 and SW480 cells. (b) HCT116 cells had a significantly higher proportion of EPCAM-positive cells compared to SW480 cells (Student's t-test; $N=5$ ). Error bars represent the standard deviation of the mean value. Scale bars: $10 \mu \mathrm{m}$. 
prosgastrin in a colon cancer cell line, indicating an increase in putative CSC (53). In addition, Giraud et al. have reported that decreased proportion of ALDH ${ }^{\text {high }}$ cells by suppression of progastrin resulted in decreased tumorigenesis and glycolytic ability and restricted the self-renewal ability of CSC (54). Thus, there may be a relationship between the Wnt signaling and CSC. In this study, SW480 cells with high Wnt activity had a significantly higher proportion of CD44-positive cells than HCT116 cells. A similar result was observed for ALDH1. SW480 cells with high Wnt activity had a significantly lower proportion of EpCAM-positive cells than HCT116 cells. While there are reports that EpCAM may be a marker of CSC, this finding remains controversial. EpCAM expression has been linked to poorer disease-free and overall survival in breast cancer (55). Gosens et al. have observed strong EpCAM staining in the tumor center and a progressive loss at the tumor front associated with poor local and overall recurrence-free survival in colorectal cancer (56). Lugli et al. have reported a correlation between the loss of membranous EpCAM and tumor invasiveness and progression (57). EpCAM overexpression was related to lymph node classification and tumor border configuration (pushing or infiltration) but not to local recurrence. These results suggest that the loss of EpCAM at the tumor border results in reduced adhesion and induces the epithelial-mesenchymal transition, resulting in lymph node and distant metastasis. Pastushenko et al. have analyzed cells that did not express EpCAM and isolated cell populations based on their expression of the mesenchymal-cell receptor proteins CD51, CD61 and CD106. The authors identified two cell populations that were the most likely to metastasize; $\operatorname{EpCAM(-),~CD106(-),~CD51(-),~}$ CD61(-) and EpCAM(-), CD106(+), CD51(-), CD61(-) (58, 59).These findings suggest that EpCAM affects metastasis and prognosis but has little direct effect on radiosensitivity.

In conclusion, nuclear accumulation of $\beta$-catenin is an indicator of active Wnt signaling. Cell lines with higher nuclear $\beta$-catenin accumulation showed resistance to radiation therapy compared to cell lines with lower accumulation, as well as a significantly higher positive proportion of putative CSC. These findings suggest that the $\mathrm{Wnt} / \beta$-catenin signaling pathway is related to radioresistance and stemness of CSC.

\section{Conflicts of Interest}

The Authors declare that they have no competing interests regarding this study.

\section{Authors' Contributions}

HTan, FH, HTom, Tmor, AH, and MM conceived and designed the experiments. HTan, MK, Tmiy, FH, Htom, Tmor, AH, and MM analyzed the data. HTan, MK, SS, RI, Htom, and Tmor wrote the first draft of the manuscript. HTan, MK, SS, Tmiy, RI, $\mathrm{FH}$, Htom, Tmor, $\mathrm{AH}$, and MM contributed to the writing of the manuscript. HTan, MK, SS, Tmiy, RI, FH, Htom, Tmor, AH, and MM agreed with the manuscript results and conclusions. HTan, MK, SS, Tmiy, RI, FH, Htom, Tmor, AH, and MM jointly developed the structure and arguments for the paper. HTan, MK, SS, Tmiy, RI, FH, Htom, Tmor, AH, and MM made critical revisions and approved the final version. HTan, MK, SS, Tmiy, $\mathrm{RI}, \mathrm{FH}, \mathrm{Htom}$, Tmor, $\mathrm{AH}$, and MM reviewed and approved the final manuscript.

\section{Acknowledgements}

The paper has been edited and rewritten by an experienced scientific editor, who has improved its grammar and stylistic expression. The Authors thank Enago, Crimson Interactive Pvt, Ltd.

\section{References}

1 Xiao YF, Yong X, Tang B, Qin Y, Zhang JW, Zhang D, Xie R and Yang SM: Notch and wnt signaling pathway in cancer: Crucial role and potential therapeutic targets (review). Int $\mathbf{J}$ Oncol 48: 437-449, 2016. PMID: 26648421. DOI: 10.3892/ijo.2015.3280

2 Tabatabai R, Linhares Y, Bolos D, Mita M and Mita A: Targeting the wnt pathway in cancer: A review of novel therapeutics. Target Oncol 12: 623-641, 2017. PMID: 28653295. DOI: 10.1007/s11523-017-0507-4

3 Wu X, Tu X, Joeng KS, Hilton MJ, Williams DA and Long F: Rac1 activation controls nuclear localization of beta-catenin during canonical wnt signaling. Cell 133: 340-353, 2008. PMID: 18423204. DOI: 10.1016/j.cell.2008.01.052

4 Zhang N, Wei P, Gong A, Chiu WT, Lee HT, Colman H, Huang H, Xue J, Liu M, Wang Y, Sawaya R, Xie K, Yung WK, Medema RH, He X and Huang S: Foxm1 promotes beta-catenin nuclear localization and controls wnt target-gene expression and glioma tumorigenesis. Cancer Cell 20: 427-442, 2011. PMID: 22014570. DOI: $10.1016 /$ j.ccr.2011.08.016

5 Kim I, Hur J and Jeong S: Hur represses wnt/beta-cateninmediated transcriptional activity by promoting cytoplasmic localization of beta-catenin. Biochem Biophys Res Commun 457: 65-70, 2015. PMID: 25534855. DOI: 10.1016/j.bbrc. 2014.12.052

6 Logan CY and Nusse R: The wnt signaling pathway in development and disease. Annu Rev Cell Dev Biol 20: 781-810, 2004. PMID: 15473860. DOI: 10.1146/annurev.cellbio.20.01 0403.113126

7 Rosenbluh J, Wang X and Hahn WC: Genomic insights into wnt/beta-catenin signaling. Trends Pharmacol Sci 35: 103-109, 2014. PMID: 24365576. DOI: 10.1016/j.tips.2013.11.007

8 Batlle E, Bacani J, Begthel H, Jonkheer S, Gregorieff A, van de Born M, Malats N, Sancho E, Boon E, Pawson T, Gallinger S, Pals $\mathrm{S}$ and Clevers $\mathrm{H}$ : Ephb receptor activity suppresses colorectal cancer progression. Nature 435: 1126-1130, 2005. PMID: 15973414. DOI: 10.1038 /nature03626

9 Katoh M: Wnt/pcp signaling pathway and human cancer (review). Oncol Rep 14: 1583-1588, 2005. PMID: 16273260. DOI: $10.3892 /$ or.14.6.1583

10 Clevers $\mathrm{H}$ and Nusse R: Wnt/beta-catenin signaling and disease. Cell 149: 1192-1205, 2012. PMID: 22682243. DOI: 10.1016/j.cell.2012.05.012 
11 Liu W, Dong X, Mai M, Seelan RS, Taniguchi K, Krishnadath KK, Halling KC, Cunningham JM, Boardman LA, Qian C, Christensen E, Schmidt SS, Roche PC, Smith DI and Thibodeau $\mathrm{SN}$ : Mutations in axin2 cause colorectal cancer with defective mismatch repair by activating beta-catenin/tcf signalling. Nat Genet 26: 146-147, 2000. PMID: 11017067. DOI: 10.1038/ 79859

12 Polakis P: Wnt signaling and cancer. Genes Dev 14: 1837-1851, 2000. PMID: 10921899. DOI: 10.1101/gad.14.15.1837

13 Holcombe RF, Marsh JL, Waterman ML, Lin F, Milovanovic T and Truong T: Expression of wnt ligands and frizzled receptors in colonic mucosa and in colon carcinoma. Mol Pathol 55: 220226, 2002. PMID: 12147710 . DOI: $10.1136 / \mathrm{mp} .55 .4 .220$

14 Moser AR, Pitot HC and Dove WF: A dominant mutation that predisposes to multiple intestinal neoplasia in the mouse. Science 247: 322-324, 1990. PMID: 2296722. DOI: 10.1126/ science. 2296722

15 Nishisho I, Nakamura Y, Miyoshi Y, Miki Y, Ando H, Horii A, Koyama K, Utsunomiya J, Baba S and Hedge P: Mutations of chromosome $5 \mathrm{q} 21$ genes in fap and colorectal cancer patients. Science 253: 665-669, 1991. PMID: 1651563. DOI: $10.1126 /$ science. 1651563

16 Kinzler KW and Vogelstein B: Lessons from hereditary colorectal cancer. Cell 87: 159-170, 1996. PMID: 8861899. DOI: 10.1016/s0092-8674(00)81333-1

17 Sparks AB, Morin PJ, Vogelstein B and Kinzler KW: Mutational analysis of the apc/beta-catenin/tcf pathway in colorectal cancer. Cancer Res 58: 1130-1134, 1998. PMID: 9515795.

18 Huang S, Fantini D, Merrill BJ, Bagchi S, Guzman G and Raychaudhuri P: Ddb2 is a novel regulator of wnt signaling in colon cancer. Cancer Res 77: 6562-6575, 2017. PMID: 29021137. DOI: 10.1158/0008-5472.CAN-17-1570

19 Wickstrom M, Dyberg C, Milosevic J, Einvik C, Calero R, Sveinbjornsson B, Sanden E, Darabi A, Siesjo P, Kool M, Kogner $\mathrm{P}$, Baryawno $\mathrm{N}$ and Johnsen JI: Wnt/beta-catenin pathway regulates mgmt gene expression in cancer and inhibition of wnt signalling prevents chemoresistance. Nat Commun 6: 8904, 2015. PMID: 26603103. DOI: 10.1038/ncomms9904 1

20 Chen B, Zhang D, Kuai J, Cheng M, Fang X and Li G: Upregulation of mir-199a/b contributes to cisplatin resistance via wnt/beta-catenin-abcg2 signaling pathway in aldha1(+) colorectal cancer stem cells. Tumour Biol 39: 1010428317715155, 2017. PMID: 28639895. DOI: $10.1177 / 1010428317715155$

21 Fischer M, Yen WC, Kapoun AM, Wang M, O’Young G, Lewicki J, Gurney A and Hoey T: Anti-dll4 inhibits growth and reduces tumor-initiating cell frequency in colorectal tumors with oncogenic kras mutations. Cancer Res 71: 1520-1525, 2011. PMID: 21193546. DOI: 10.1158/0008-5472.CAN-10-2817

22 Osada T, Chen M, Yang XY, Spasojevic I, Vandeusen JB, Hsu D, Clary BM, Clay TM, Chen W, Morse MA and Lyerly HK: Antihelminth compound niclosamide downregulates wnt signaling and elicits antitumor responses in tumors with activating apc mutations. Cancer Res 71: 4172-4182, 2011. PMID: 21531761. DOI: 10.1158/0008-5472.CAN-10-3978

23 Zhang Y, Li Q, Zhou D and Chen H: Genistein, a soya isoflavone, prevents azoxymethane-induced up-regulation of wnt/beta-catenin signalling and reduces colon pre-neoplasia in rats. Br J Nutr 109: 33-42, 2013. PMID: 22716201. DOI: $10.1017 / \mathrm{S} 0007114512000876$
24 Valkenburg KC, Graveel CR, Zylstra-Diegel CR, Zhong Z and Williams BO: Wnt/beta-catenin signaling in normal and cancer stem cells. Cancers (Basel) 3: 2050-2079, 2011. PMID: 24212796. DOI: $10.3390 /$ cancers3022050

25 Morgan RG, Ridsdale J, Tonks A and Darley RL: Factors affecting the nuclear localization of beta-catenin in normal and malignant tissue. J Cell Biochem 115: 1351-1361, 2014. PMID: 24610469. DOI: $10.1002 /$ jcb.24803

26 Du L, Wang H, He L, Zhang J, Ni B, Wang X, Jin H, Cahuzac N, Mehrpour M, Lu Y and Chen Q: Cd44 is of functional importance for colorectal cancer stem cells. Clin Cancer Res 14: 6751-6760, 2008. PMID: 18980968. DOI: 10.1158/10780432.CCR-08-1034

27 Hatano Y, Fukuda S, Hisamatsu K, Hirata A, Hara A and Tomita $\mathrm{H}$ : Multifaceted interpretation of colon cancer stem cells. Int J Mol Sci 18, 2017. PMID: 28678194. DOI: 10.3390/ijms18071446

28 Wang C, Xie J, Guo J, Manning HC, Gore JC and Guo N: Evaluation of cd44 and cd133 as cancer stem cell markers for colorectal cancer. Oncol Rep 28: 1301-1308, 2012. PMID: 22895640. DOI: 10.3892/or.2012.1951

29 Sahlberg SH, Spiegelberg D, Glimelius B, Stenerlow B and Nestor M: Evaluation of cancer stem cell markers cd133, cd44, cd24: Association with akt isoforms and radiation resistance in colon cancer cells. PLoS One 9: e94621, 2014. PMID: 24760019. DOI: 10.1371/journal.pone.0094621

30 Phillips TM, McBride WH and Pajonk F: The response of cd24(/low)/cd44+ breast cancer-initiating cells to radiation. J Natl Cancer Inst 98: 1777-1785, 2006. PMID: 17179479. DOI: 10.1093/jnci/djj495

31 Croker AK and Allan AL: Inhibition of aldehyde dehydrogenase (aldh) activity reduces chemotherapy and radiation resistance of stem-like aldhhicd44(+) human breast cancer cells. Breast Cancer Res Treat 133: 75-87, 2012. PMID: 21818590. DOI: 10.1007/s10549-011-1692-y

32 Yoshida A: Molecular genetics of human aldehyde dehydrogenase. Pharmacogenetics 2: 139-147, 1992. PMID: 1306115 DOI: 10.1097/00008571-199208000-00001

33 Huang EH, Hynes MJ, Zhang T, Ginestier C, Dontu G, Appelman H, Fields JZ, Wicha MS and Boman BM: Aldehyde dehydrogenase 1 is a marker for normal and malignant human colonic stem cells (sc) and tracks sc overpopulation during colon tumorigenesis. Cancer Res 69: 3382-3389, 2009. PMID: 19336570. DOI: 10.1158/0008-5472.CAN-08-4418

34 Kahlert C, Gaitzsch E, Steinert G, Mogler C, Herpel E, Hoffmeister M, Jansen L, Benner A, Brenner H, Chang-Claude J, Rahbari N, Schmidt T, Klupp F, Grabe N, Lahrmann B, Koch M, Halama N, Buchler M and Weitz J: Expression analysis of aldehyde dehydrogenase 1a1 (aldh1a1) in colon and rectal cancer in association with prognosis and response to chemotherapy. Ann Surg Oncol 19: 4193-4201, 2012. PMID: 22878609. DOI: $10.1245 / \mathrm{s} 10434-012-2518-9$

35 Tomita H, Tanaka K, Tanaka $\mathrm{T}$ and Hara A: Aldehyde dehydrogenase 1a1 in stem cells and cancer. Oncotarget 7: 1101811032, 2016. PMID: 26783961. DOI: 10.18632/oncotarget.6920

36 Chen YC, Chen YW, Hsu HS, Tseng LM, Huang PI, Lu KH, Chen DT, Tai LK, Yung MC, Chang SC, Ku HH, Chiou SH and Lo WL: Aldehyde dehydrogenase 1 is a putative marker for cancer stem cells in head and neck squamous cancer. Biochem Biophys Res Commun 385: 307-313, 2009. PMID: 19450560. DOI: $10.1016 /$ j.bbrc. 2009.05 .048 
37 Mihatsch J, Toulany M, Bareiss PM, Grimm S, Lengerke C, Kehlbach $\mathrm{R}$ and Rodemann HP: Selection of radioresistant tumor cells and presence of aldh1 activity in vitro. Radiother Oncol 99: 300-306, 2011. PMID: 21704411. DOI: 10.1016/ j.radonc.2011.06.003

38 Ni J, Cozzi PJ, Duan W, Shigdar S, Graham PH, John KH and Li Y: Role of the epcam (cd326) in prostate cancer metastasis and progression. Cancer Metastasis Rev 31: 779-791, 2012. PMID: 22718399. DOI: 10.1007/s10555-012-9389-1

39 Patriarca C, Macchi RM, Marschner AK and Mellstedt H: Epithelial cell adhesion molecule expression $(\mathrm{cd} 326)$ in cancer: A short review. Cancer Treat Rev 38: 68-75, 2012. PMID: 21576002. DOI: 10.1016/j.ctrv.2011.04.002

40 Dalerba P, Dylla SJ, Park IK, Liu R, Wang X, Cho RW, Hoey T, Gurney A, Huang EH, Simeone DM, Shelton AA, Parmiani G, Castelli $\mathrm{C}$ and Clarke MF: Phenotypic characterization of human colorectal cancer stem cells. Proc Natl Acad Sci USA 104: 10158-10163, 2007. PMID: 17548814. DOI: 10.1073/pnas. 0703478104

41 Ni J, Cozzi P, Hao J, Beretov J, Chang L, Duan W, Shigdar S, Delprado W, Graham P, Bucci J, Kearsley J and Li Y: Epithelial cell adhesion molecule (epcam) is associated with prostate cancer metastasis and chemo/radioresistance via the pi3k/akt/mtor signaling pathway. Int J Biochem Cell Biol 45: 2736-2748, 2013. PMID: 24076216. DOI: 10.1016/j.biocel.2013.09.008

42 Hao L, Zhao Y, Wang Z, Yin H, Zhang X, He T, Song S, Sun S, Wang B, Li Z and Su Q: Expression and clinical significance of sall4 and beta-catenin in colorectal cancer. J Mol Histol 47: 117128, 2016. PMID: 26779651. DOI: 10.1007/s 10735-016-9656-5

43 Qin Y, Tang B, Hu CJ, Xiao YF, Xie R, Yong X, Wu YY, Dong $\mathrm{H}$ and Yang SM: An htert/zeb1 complex directly regulates ecadherin to promote epithelial-to-mesenchymal transition (emt) in colorectal cancer. Oncotarget 7: 351-361, 2016. PMID: 26540342. DOI: 10.18632 /oncotarget.5968

44 El-Bahrawy M, Poulsom R, Rowan AJ, Tomlinson IT and Alison MR: Characterization of the e-cadherin/catenin complex in colorectal carcinoma cell lines. Int J Exp Pathol 85: 65-74, 2004. PMID: 15154912. DOI: 10.1111/j.0959-9673.2004.0371.x

45 Karimaian A, Majidinia M, Bannazadeh Baghi H and Yousefi B: The crosstalk between wnt/beta-catenin signaling pathway with DNA damage response and oxidative stress: Implications in cancer therapy. DNA Repair (Amst) 51: 14-19, 2017. PMID: 28108274. DOI: 10.1016/j.dnarep.2017.01.003

46 Fodde R and Brabletz T: Wnt/beta-catenin signaling in cancer stemness and malignant behavior. Curr Opin Cell Biol 19: 150158, 2007. PMID: 17306971. DOI: 10.1016/j.ceb.2007.02.007

47 Vermeulen L, De Sousa EMF, van der Heijden M, Cameron K, de Jong JH, Borovski T, Tuynman JB, Todaro M, Merz C, Rodermond H, Sprick MR, Kemper K, Richel DJ, Stassi G and Medema JP: Wnt activity defines colon cancer stem cells and is regulated by the microenvironment. Nat Cell Biol 12: 468-476, 2010. PMID: 20418870. DOI: $10.1038 /$ ncb2048

48 de Sousa EM, Vermeulen L, Richel D and Medema JP: Targeting wnt signaling in colon cancer stem cells. Clin Cancer Res 17: 647-653, 2011. PMID: 21159886. DOI: 10.1158/10780432.CCR-10-1204

49 Hirsch D, Barker N, McNeil N, Hu Y, Camps J, McKinnon K, Clevers H, Ried T and Gaiser T: Lgr5 positivity defines stemlike cells in colorectal cancer. Carcinogenesis 35: 849-858, 2014. PMID: 24282287. DOI: $10.1093 /$ carcin/bgt377
50 Koh TJ, Bulitta CJ, Fleming JV, Dockray GJ, Varro A and Wang TC: Gastrin is a target of the beta-catenin/tcf-4 growth-signaling pathway in a model of intestinal polyposis. J Clin Invest 106: 533-539, 2000. PMID: 10953028. DOI: 10.1172/JCI9476

51 Kim PJ, Plescia J, Clevers H, Fearon ER and Altieri DC: Survivin and molecular pathogenesis of colorectal cancer. Lancet 362: 205-209, 2003. PMID: 12885482. DOI: 10.1016/S01406736(03)13910-4

52 Pannequin J, Delaunay N, Buchert M, Surrel F, Bourgaux JF, Ryan J, Boireau S, Coelho J, Pelegrin A, Singh P, Shulkes A, Yim M, Baldwin GS, Pignodel C, Lambeau G, Jay P, Joubert D and Hollande F: Beta-catenin/tcf-4 inhibition after progastrin targeting reduces growth and drives differentiation of intestinal tumors. Gastroenterology 133: 1554-1568, 2007. PMID: 17920061. DOI: $10.1053 /$ j.gastro.2007.08.023

53 Jin G, Westphalen CB, Hayakawa Y, Worthley DL, Asfaha S, Yang X, Chen X, Si Y, Wang H, Tailor Y, Friedman RA and Wang TC: Progastrin stimulates colonic cell proliferation via cck2r- and beta-arrestin-dependent suppression of bmp2. Gastroenterology 145: 820-830 e810, 2013. PMID: 23891976. DOI: $10.1053 /$ j.gastro.2013.07.034

54 Giraud J, Failla LM, Pascussi JM, Lagerqvist EL, Ollier J, Finetti P, Bertucci F, Ya C, Gasmi I, Bourgaux JF, Prudhomme M, Mazard T, Ait-Arsa I, Houhou L, Birnbaum D, Pelegrin A, Vincent C, Ryall JG, Joubert D, Pannequin J and Hollande F: Autocrine secretion of progastrin promotes the survival and self-renewal of colon cancer stem-like cells. Cancer Res 76: 3618-3628, 2016. PMID: 27197176. DOI: 10.1158/0008-5472.CAN-15-1497

55 Gastl G, Spizzo G, Obrist P, Dunser M and Mikuz G: Ep-cam overexpression in breast cancer as a predictor of survival. Lancet 356: 1981-1982, 2000. PMID: 11130529. DOI: 10.1016/S01406736(00)03312-2

56 Gosens MJ, van Kempen LC, van de Velde CJ, van Krieken JH and Nagtegaal ID: Loss of membranous ep-cam in budding colorectal carcinoma cells. Mod Pathol 20: 221-232, 2007. PMID: 17361206. DOI: 10.1038/modpathol.3800733

57 Lugli A, Iezzi G, Hostettler I, Muraro MG, Mele V, Tornillo L, Carafa V, Spagnoli G, Terracciano L and Zlobec I: Prognostic impact of the expression of putative cancer stem cell markers cd133, cd166, cd44s, epcam, and aldh1 in colorectal cancer. $\mathrm{Br}$ J Cancer 103: 382-390, 2010. PMID: 20606680. DOI: 10.1038/sj.bjc.6605762

58 Pastushenko I, Brisebarre A, Sifrim A, Fioramonti M, Revenco T, Boumahdi S, Van Keymeulen A, Brown D, Moers V, Lemaire S, De Clercq S, Minguijon E, Balsat C, Sokolow Y, Dubois C, De Cock F, Scozzaro S, Sopena F, Lanas A, D'Haene N, Salmon I, Marine JC, Voet T, Sotiropoulou PA and Blanpain C: Identification of the tumour transition states occurring during emt. Nature 556: 463-468, 2018. PMID: 29670281. DOI: 10.1038/s41586-018-0040-3

59 Thompson EW and Nagaraj SH: Transition states that allow cancer to spread. Nature 556: 442-444, 2018. PMID: 29686367. DOI: $10.1038 / \mathrm{d} 41586-018-04403-\mathrm{x}$

Received September 29, 2019

Revised November 16, 2019

Accepted November 18, 2019 